\title{
MOBILE 5G TECHNOLOGY ADOPTION INVESTMENT TIMING DECISION MAKERS CLUSTERING AND WILLINGNESS TO INVEST UNDER VOLATILE DEMAND CHANGES
}

\author{
Saulius Adamauskas ${ }^{1}$, Rytis Krušinskas²
}

\begin{abstract}
Enterprises need to identify the optimal timing for technological change in order to increase competitiveness and increase the value of the company in an uncertain demanding environment. Investment decisions for adopting new technologies are costly and sometimes risky because technological investments are irreversible. To simulate the process, comprehensive technological adoption regarding investment timing was used in a management decision support model. The constructed model is structured as follows: 1) historical demand paths analysis; 2) application of statistical data validity tests; 3) the forecast of market parameters regarding data arrays using the geometric Brownian motion method, based on Monte Carlo simulation; 4) determination of technological life cycle using a Hodrick-Prescott filter; 5) technological adoption time-window determination; and 6) calculation of company net present values (NPV) based on change in free cash-flow. The model for mature 5G mobile markets, created and empirical tested, was performed in relation to 18 largest Europe mobile service providers, as potential decision makers operating across 33 countries. Results confirmed that selection of the technological investment time depends on companies' strategic financial decisions and financial state. The performed simulations revealed the consequence of 5G technology investment for investor roles, clustered according to financial data within a 5-year period (2010-2014). The analyzed companies were assigned to roles of pioneers-innovators, pragmatics, followers, or laggards. Finally, it is assumed and argued that financial parameters indicate the willingness to adopt new technologies in a global technologically changing environment.
\end{abstract}

JEL Classification Numbers: O16, O32, O33 DOI: http://dx.doi.org/10.12955/cbup.v4.853

Keywords: optimal investment timing, geometric Brownian motion, 5G technology adoption.

\section{Introduction}

Revolutionary changes in the market affect economic development and its growth rates. Within stochastic innovational processes, uncertainties can be found that encompass generations of new technologies, their development, and a technologically changing environment. Due to this, in recent decades, academic research and literature have been focused on analyzing technological development, efficiency of usage, investment timing issues, and integration within business and economic environment. This has resulted in technologies that are multidisciplinary and interrelated between different industries, supply chains, ecosystems, society, and other entities. Thus, in a globally volatile environment, competing companies with activities based on technologic resources are forced to make strategic decisions about the management of technology. Thus, paradigms of innovation and technological development become an inseparable part of the global economic development. From this point of view, these paradigms could be considered as competitive advantages. A variety of technologic achievements in different economic sectors, such as information technologies, chemistry, energetics, medicine, electronics, and other industries, have features that rapidly change and this constrains the forecasting and predictions previously mentioned regarding the development and aggregation of paradigms. For these reasons, companies need to involve technological adoption, development, and upgrade issues into strategic decisions to keep and increase competitiveness. Due to a volatile environment, companies are following every innovation, and are forced to invest in risky projects in order to not miss a possible technological leap in the market as well as the opportunity to commercialize new technologies more rapidly than ever before.

The technological upgrades, turnovers, or shifts are complex processes related to high risk in organizational systems, processes, products, services, and industries. Consequently, those companies that aim to manage technological risks, in this way, remain competitive by a variety of means, which includes the company's internal resources; macro-economic factors, such as demand, product,

\footnotetext{
${ }^{1}$ Saulius Adamauskas, School of Economics and Business, Kaunas University of Technology, saulius.adamauskas@ktu.lt

${ }^{2}$ Rytis Krušinskas, School of Economics and Business, Kaunas University of Technology, email: rytis.krusinskas @ktu.lt
} 
industry, and technology life cycles; and social environment. The analysis of academic literature shows that timing in technological investment or adoption is most crucial for managing the optimal technological change in terms of successful products and services or both, or remaining competitive in the market, as well as financially sustainable. Certain technological management decisions could be implemented only at certain times, because technologies develop faster than industry.

\section{Literature Review}

Many fundamental works, dedicated to solving problems in the development of technologies within the theoretical framework, were created. Such authors are Schon (1967), Friar and Horwitch (1985), Bohn (1994), Drejer (2000), Stock and Tatikonda (2000), Perez (2001, 2002, 2009), Jaffe et. al (2002), Rogers (2003, 2010), Ireland and Webb (2007), Rothaermel (2008), Heffner and Sharif (2008), Kaplan and Tripsas (2008), and Tan, Chong, Lin and Ezeet al. (2009) who provide fundamental background and benchmarks for theoretical and practical studies in technological change. Well-known authors who have continued analysis in the technological change environment are Jones (2005), Mokyr (2005), Crabtree (2006), Grossmann and Steger (2007), Teixeira (2012), Gorodnichenko and Schnitzer (2013), and others. These have studied fundamental sources of economic growth and development, with emphasis on technological fields and opportunities for learning of technology.

Recent developments in economic life cycles and recent academic studies were performed by Hsueh (2011), Verganti (2011), Taylor and Taylor (2012), Pol (2012), Shahmarichatghieh, Tolonen and Haapasalo (2015), Lobel, Patel, Vulcano and Zhang (2015), and others. Market timing decisions cover multi-disciplinary issues in strategic management. Especially, the frequent defining of optimal timing in the previous years' academic literature involving a variety of elements underlined by Krušinskas and Vasiliauskaitė (2005), Moon (2010), Wong (2010, 2011), Henderson (2010), Butler, Cornaggia, Grullon and Weston (2011), Svensson, Strömberg and Patriksson (2011), Yagi and Takashima (2012), Bolton, Chen and Wang. (2013), Chou, Sung, Lin and Jahn (2014), Hagspiel, Huisman and Nunes (2015), and others. Nonetheless, as pointed out by Chen and Ma (2014), most literature regarding technological adoption relates to the perspective of the psychological acceptance of new technologies by individual users or organizations.

In today's intensive development of the global economy, companies are challenged to remain competitive and continue to offer customers a line of innovative and state-of-the-art technology, in products and services. Thus, in technologically intensive industries, investments in technological adoption are inevitable and methods of assessing investment timing and competitiveness have been analyzed by such authors as Scarso (1996), David, Hitt and Gimeno (2001), Krishnan and Loch (2005), Kor (2006), Bouis et al. (2006), Pertile (2007), Bhaskaran and Ramachandran (2011), Jakšić and Jakšić (2012), Martinez (2013), Hori and Osano (2013), Biagini et al. (2014), and others. In general, authors focus on the conception of technological innovations, their efficient models in different industries, and the aspects of value creation for the company. From a variety of optimal timing studies, different types of decision support models have been investigated by authors, such as Bar-Han \& Maimon (1993), Benaroch and Kauffman (1999), Krušinskas and Vasiliauskaite (2005), Kamarianakis and Xepapadeas (2006), Mukherji et al. (2006), Ngwenyama et al. (2007), Huang and Da (2007), Wickart and Madlener (2007), Pertile (2007), Wong (2010, 2011), Moon (2010), Henderson (2010), Shibata and Nishihara (2011), Whalley (2011), Yagi and Takashima (2012), Bolton et al. (2013), Wong and Yi (2013), Nishihata and Shibata (2013), Feil and Musshoff (2013), Kim, Lee and Sohn (2014), Jeon and Nishihara (2014), and others.

In general, research, development, and innovation empower a company to increase productivity to create new products, improve the quality of products, and reduce existing costs. Furthermore, science, technology, and innovation affect society and its development through growth in gross domestic product GDP, creating and optimizing new jobs, increasing a country's image compared with other countries and creating a relevant environment for other businesses to start the circle again. Moreover, research, development, and innovation could produce positive spillover effects in other companies, sectors, and countries and these could be significant for a country's economic development. Technological innovation is a result of the interaction of research and development $(R \& D)$ and entrepreneurial dimensions, executed in the network of organizations that create knowledge. This 
shows the growing importance of timing, marketing, quality management, and investments. Therefore, it is critical to identify such companies and environmental issues that are required to maintain science and technology ( $\mathrm{S} \& \mathrm{~T}$ ) and $\mathrm{R} \& \mathrm{D}$ activities. It is necessary to examine, identify, and develop a company's unique set of resources and capacities, to assimilate opportunities provided by the environment, and avoid restrictions imposed by the company's internal assets.

After an analysis of academic literature, it could be stated, that the optimal timing of investing in technological adoption should include an analysis of the historical development of products or services or both with demand paths showing volatility as well as the technological life cycle. Furthermore, the uncertainty of demand in the future needs to be projected and the technology life cycle continuity integrated beyond that of the actual data. Through the data arrays in the analysis, being crucial for the technological development, the volatility of demand and behavior investment parameters should be considered. These combined empower those choosing to optimize the timing of investing in technological adoption for competiveness in the market.

\section{Data and Methodology}

In the world's markets, players currently compete not only by attracting potential customers with ordinary products and services, but by "looking out of the box". In other words, in this rapidly growing technological era, all science and technology based companies eventually comprehend that the pool of customers is not growing as rapidly as it did in the early part of the 21 st century. Hence, successful businesses stand on the business life platform, which has an existence period. In past research, Adamauskas and Krušinskas (2016), created a theoretically comprehensive support model for managing the timing of investment in technological adoption (a brief summary of the model is presented in Table 1) and performed the empirical testing of this model in a potential 5G (5th generation mobile networks or 5th generation wireless systems) technology market, within 18 of the largest European mobile service providers representing the decision-makers operating in 33 countries.

According to Adamauskas and Krušinskas (2016), the model calculates the optimal timing for mobile $5 \mathrm{G}$ technology investment and reveals the decision value expressed as a $\mathrm{TF}_{\mathrm{c}}$ ratio, which shows the proportion between value calculated, based on net present value (NPV) of free cash flow (FCF) with discount factor as return on capital employed (ROCE). The time period analyzed involved 37 quarters, starting from the fourth quarter of 2005 and ending in the 2014 Q4. Next, demand parameters for the forthcoming 10-year period was projected. Simulation results revealed that mobile $5 \mathrm{G}$ standards are expected to be operating in 2019-2020 with a technological peak period at Y2024. The results of Hodrick-Prescott filter were logically validated and forecasted the beginning of 5G technology generation in the first quarter of 2018. The results showed that the window of investment started at Y2014 and ended at Y2019. In other words, 4.3-10.5 years starting from Y2024.

From a financial management and technological adoption point of view, it could be said that, despite all market players having same information and technological surrounding, investment timing for technological adoption should be varied depending on the financial state of the market participants. Nonetheless, this research aimed to create clusters of selected companies in investor roles such as pioneers-innovators. pragmatics. followers, and laggards (Rogers (2003) and define these financial parameters: capital expenditure (CAPEX) to revenues, return on capital employed, EBIT, EBITDA, and proportion of value created after the period analyzed to the current market value, $\mathrm{TF}_{\mathrm{c}}$. It was assumed and argued that the financial parameters indicated a willingness to adopt new technologies in global technological environments. Selected markets involved such countries as Austria, Belarus, Belgium, Bulgaria, Croatia, Czech Republic, Denmark, Estonia, Finland, France, Germany, Greece, Hungary, Ireland, Italy, Latvia, Lithuania, the Netherlands, Norway, Poland, Portugal, Romania, Russia, Serbia, Slovakia, Slovenia, Spain, Sweden, Switzerland, Turkey, Ukraine, and United Kingdom (market data selection was limited to data availability, and thus, in this research, it was assumed, that these countries and companies operated in the mobile network market). Annual financial statements of the 18 market participants were analyzed in a 5-year period (2010-2014) and the parameters of the clusters were calculated by averaging the market players' financial indicators according to the investor role assigned. 
Table 1: The structure of a comprehensive decision support model for managing the timing of investment in technological adoption

\begin{tabular}{|c|c|c|}
\hline Instruments/Measures & Stage & Results \\
\hline $\begin{array}{l}\text { Actual historical data: market data, } \\
\text { previous academic research data, } \\
\text { statistical analysis and synthesis of } \\
\text { fragmentary knowledge on the subject. }\end{array}$ & $\begin{array}{l}\text { 1. Historical demand } \\
\text { paths analysis }\end{array}$ & $\begin{array}{l}\text { 1. It is assumed that demand volatility depends on } \\
\text { two parameters: } \\
\text { - Average market revenues (Revenues) } \\
\text { - Quantity of subscribers (Subscribers). } \\
\text { 2. Determination of mentioned parameters dynamics } \\
\text { and growth rates in terms of selected geographical } \\
\text { area as well as the penetration rates changes. } \\
\text { 3. Current and previous mobile technology } \\
\text { generation development features. }\end{array}$ \\
\hline $\begin{array}{l}\text { Determination of average market } \\
\text { revenues (Revenues) and Subscribers } \\
\text { dynamics statistical validity tests. }\end{array}$ & $\begin{array}{l}\text { 2. Statistical data } \\
\text { validity tests }\end{array}$ & $\begin{array}{l}\text { Statistical validity tests applied: } \\
\text { 1. Dickey - Fuller test (for stationarity of both time } \\
\text { series). } \\
\text { 2. Q-Q plots (ascertain of Normal distribution). } \\
\text { 3. Autocorrelation test } \\
\text { 4. Kolmogorov-Smirnov test (ascertain of Normal } \\
\text { distribution) }\end{array}$ \\
\hline $\begin{array}{l}\text { 1. Determination of demand paths }-40 \\
\text { iterations of both Revenues and } \\
\text { Subscribers projected. } \\
\text { 2. Determination of MARPU (Market } \\
\text { Average Revenue Per User) } \\
\text { 3. Dynamics and statistical analysis and } \\
\text { synthesis of fragmentary knowledge on } \\
\text { the subject. }\end{array}$ & $\begin{array}{l}\text { 3. The forecast of data } \\
\text { array using geometric } \\
\text { Brownian motion } \\
\text { method based on Monte } \\
\text { Carlo simulation }\end{array}$ & $\begin{array}{l}\text { Geometric Brownian Motion (hereafter, GBM) } \\
\text { process based on Monte Carlo simulation used to } \\
\text { define forecasted parameters below }{ }^{3} \text { : } \\
\text { 1. } 40 \text { iterations of market Revenues. } \\
\text { 2. } 40 \text { iterations of Subscribers. } \\
\text { 3. } 40 \text { values of MARPU rate. }\end{array}$ \\
\hline $\begin{array}{l}\text { Determination of mobile technology } \\
\text { life cycle in accordance of historical } \\
\text { (stage I) and forecasted data (stage III). }\end{array}$ & $\begin{array}{l}\text { 4. Determination of } \\
\text { technology life cycle } \\
\text { using Hodrick - } \\
\text { Prescott filter }\end{array}$ & $\begin{array}{l}\text { Hodrick-Prescott filter used to define the stages and } \\
\text { maturity of upcoming new } 5 \mathrm{G} \text { mobile technology. }\end{array}$ \\
\hline $\begin{array}{l}\text { Optimal investment timing window for } \\
\text { each service provider (market player; } \\
\text { according to financial data availability) } \\
\text { calculated based on separate market } \\
\text { player financial data and previous } \\
\text { model stages results in terms of } \\
\text { CAPEX payback terms. These } \\
\text { parameters present the time moment } \\
\text { according to technology life cycle } \\
\text { (considered as optimal investment } \\
\text { timing moment), when the market } \\
\text { player shall start investing into new } \\
\text { mobile technology adoption. }\end{array}$ & $\begin{array}{l}\text { 5. Technology adoption } \\
\text { time window } \\
\text { determination }\end{array}$ & $\begin{array}{l}\text { Technology Adoption Window ratios shall be } \\
\text { determined for each market player in selected } \\
\text { geographical area based on two different methods: } \\
\text { 1. Method. Parameters defined: } \\
\text { - Actual Capex to Revenues ratios for each player; } \\
\text { - Stand dev. from mean rates for each player; } \\
\text { - Forecasted CAPEX to Revenues ratios for each } \\
\text { company (hereafter, CR }) \text {; } \\
\left.\text { - Technology Adoption Window (hereafter, } T A W_{c}^{l}\right) \text {. } \\
\text { 2. Method. Parameters defined: } \\
\text { - Market CAPEX values (Market CAPEX } 2) \text {; } \\
\text { - Forecasted CAPEX to Revenues ratios for each } \\
\text { company (hereafter, NCR }) \text {; } \\
\text { - Technology Adoption Window }\left(T A W_{c}^{2}\right) \text {. }\end{array}$ \\
\hline $\begin{array}{l}\text { Net present values (hereafter, NPV) for } \\
\text { each market player calculated as well } \\
\text { as companies' values based on Free } \\
\text { Cash Flow changes. On purpose to } \\
\text { appreciate the impact of decision } \\
\text { timing, relationship with Market } \\
\text { Capitalization determined. Two } \\
\text { scenarios shall be applied in terms of } \\
\text { individual ROCE or average ROCE } \\
\text { selection. }\end{array}$ & $\begin{array}{l}\text { 6. Company value } \\
\text { (NPV) calculation based } \\
\text { on Free Cash Flow } \\
\text { changes }\end{array}$ & $\begin{array}{l}\text { Net Present Values shall be determined in the } \\
\text { Plateau of upcoming 5G mobile technology life } \\
\text { cycle. NPV to Market Capitalization ratio shall be } \\
\text { determined as a proportion of value created after } \\
\text { period analyzed to the current market value. } \\
\text { Additional parameters defined: } \\
\text { - Forecasted Free Cash Flows values for each player } \\
\left(\mathrm{FCF}_{\mathrm{c})} \text {; }\right. \\
\text { - Return on Capital Employed (hereafter, ROCE }{ }_{\mathrm{c}} \text { ); } \\
\text { - Average Market Return On Capital Employed } \\
\text { (hereafter, ROCEavg.); } \\
\text { - Continuous value for each player (hereafter, } \\
\text { Con } \mathrm{V}_{\mathrm{c}} \text { ); } \\
\text { - Proportion of value created after period analyzed } \\
\text { to the current market value (hereafter, } \mathrm{TF}_{\mathrm{c}} \text { ). }\end{array}$ \\
\hline
\end{tabular}

\footnotetext{
${ }^{3}$ The amount of 40 iterations is used to calculate 10 -year period, while each iteration is quarterly based.
} 


\section{Results and Discussion}

Despite companies having similar information about the volatile changes in demand, the technological development cycle and past inventions, each company had different investment roles with different financial resources. Thus, the entry to the technological adoption cycle had various parameters. Considering the moment of technological adoption (calculated as time before peak of technological life cycle), 18 competing companies were assigned investor roles as follows: 9-10 years until technological peak were pioneers-innovators; 8 years were pragmatics; 7 years were followers; and 4 5 years were laggards (Table 2 ).

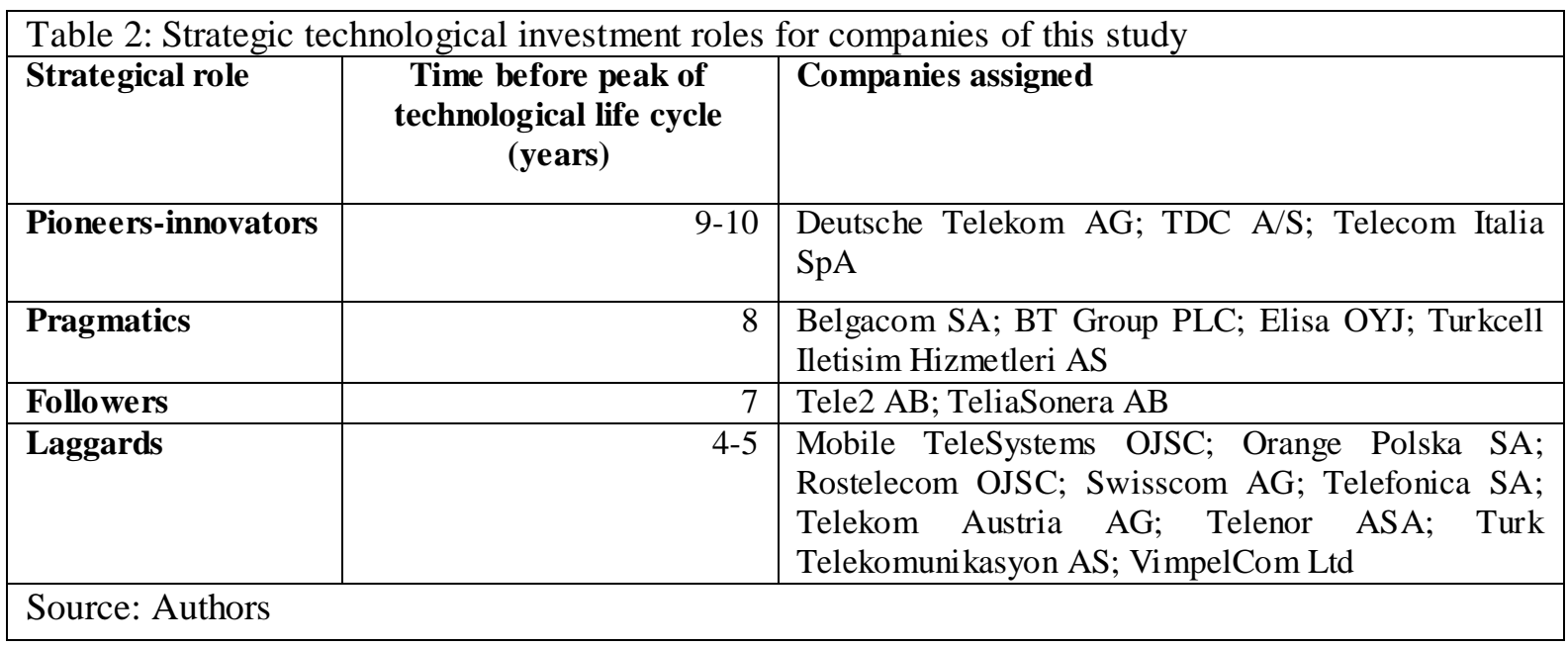

In Table 3, the average financial ratios are presented according to the different investor roles. It was found that the earlier a company started to adopt new technologies, the higher the company share (proportion) of its market capitalization (as at December 31, 2014) will be generated, or in other words, $\mathrm{TF}_{\mathrm{c}}$ was highest for pioneers-innovators with an average ratio up to $84.2 \%$ (individual ROCE) and $58.2 \%$ (average ROCE). Meanwhile, the individual and average ROCE for pragmatics was $37.8 \%$ and $44.6 \%$, respectively. Followers had the smallest proportion of market capitalization with an average value of only $21.0 \%$ and $18.0 \%$, respectively. Individual company ROCE ratios were achieved from each company's finances. Meanwhile, the average ROCE was calculated using all selected companies' averaged finances.

\begin{tabular}{|c|c|c|c|c|c|c|}
\hline Investor roles & $\begin{array}{c}\text { CAPEX to Revenues } \\
\%\end{array}$ & $\underset{\%}{\mathrm{ROCE}}$ & $\begin{array}{c}\text { EBIT } \\
\%\end{array}$ & $\begin{array}{c}\text { EBITDA } \\
\%\end{array}$ & $\begin{array}{c}\mathbf{T F}_{\mathrm{c}} \\
\%\end{array}$ & $\begin{array}{l}\mathbf{T F}_{\mathrm{c}}{ }^{2} \\
\%\end{array}$ \\
\hline $\begin{array}{l}\text { Pioneers- } \\
\text { innovators }\end{array}$ & 11.11 & 6.15 & 12.67 & 44.06 & 84.2 & 58.2 \\
\hline Pragmatics & 13.24 & 16.65 & 17.17 & 31.53 & 37.8 & 44.6 \\
\hline Followers & 15.08 & 10.06 & 15.20 & 28.35 & 21.0 & 18.0 \\
\hline Laggards & 23.61 & 12.94 & 17.92 & 41.18 & 37.9 & 41.1 \\
\hline
\end{tabular}

The batch size of companies had more than EUR 561 million of assets and EUR 278 million of revenues (5-year average as of 2010-2014). Selected companies generated more than EUR 551 million of EBITDA and spent more than EUR 203 million of CAPEX in a 5-year period. It should be noted, that the average growth rate of EBITDA was negative from 2012 and equaled $-1.13 \%$. Meanwhile, the sales growth ratio was positive and average value was $2.78 \%$. The 5 -year average return on capital employment was $14.70 \%$ with a maximum $40.18 \%$ and minimum $-4.71 \%$. The average in each year of technological efficiency ratio (TFE $=$ EBIT $\div$ Non-current assets) decreased from $16.75 \%$ in 2010 to $40.00 \%$ in 2014 . However, the average TFE in the 5-year period reached $14.38 \%$. The average 5-year CAPEX to revenues ratio was $18.30 \%$, which meant that up to a fifth of the revenue would be allocated for capital expenditure. It is noted that the ratio increased in the 5-year period: $15.47 \%$ in 2010 and $17.20 \%$ in 2014 with an extraordinary ratio in 2013, and the CAPEX to revenues reached $23.85 \%$. Another important insight was that the CAPEX growth rates had an average 
growth of $8.00 \%$ in the fifth year. However, in the period analyzed the ratios decreased from $22.58 \%$ to $-3.31 \%$, which meant that mobile service providers were either reducing the CAPEX or the current technology did not require such high capital expenditure. The results of the model and clustering are graphically presented in Figure 1.

The first wave (gray shaded area) represents the life cycle of the current 4G (LTE, a 4G mobile communications standard) mobile generation, while the second wave shows the life cycle of the future mobile 5G generation. The upper line (blue) shows the technological investment hype life-cycle. Market players were distributed according to the investment time windows, where investment strategies could be assigned with crucial insights: pioneers--innovators had the lowest CAPEX to revenues ratio (13.24\%) and the highest EBITDA (44.06\%) in comparison with pragmatics $(31.53 \%)$ and followers $(28.35 \%)$. This can be explained by a long investment period, where depreciation had affected EBITDA calculation. On one hand, the EBIT (12.67\%) was the lowest in comparison with other strategies of (17.77\% and $15.20 \%$, respectively). On the other hand, the latest market players had the highest CAPEX to revenues ratio $(23.61 \%)$ and almost the same EBITDA as innovators with $41.18 \%$. Thus, CAPEX to revenues ratio, as the variable that reflects the returns after capital expenditure the most, could be used to determine the optimal timing for investing in technological adoption in the context of the model. According to the results, such parameters as CAPEX to revenues, ROCE, EBIT, and EBITDA indicate the investor roles with a willingness to invest and empower market players to model their expected financial status for the future under the influence of technological adoption.

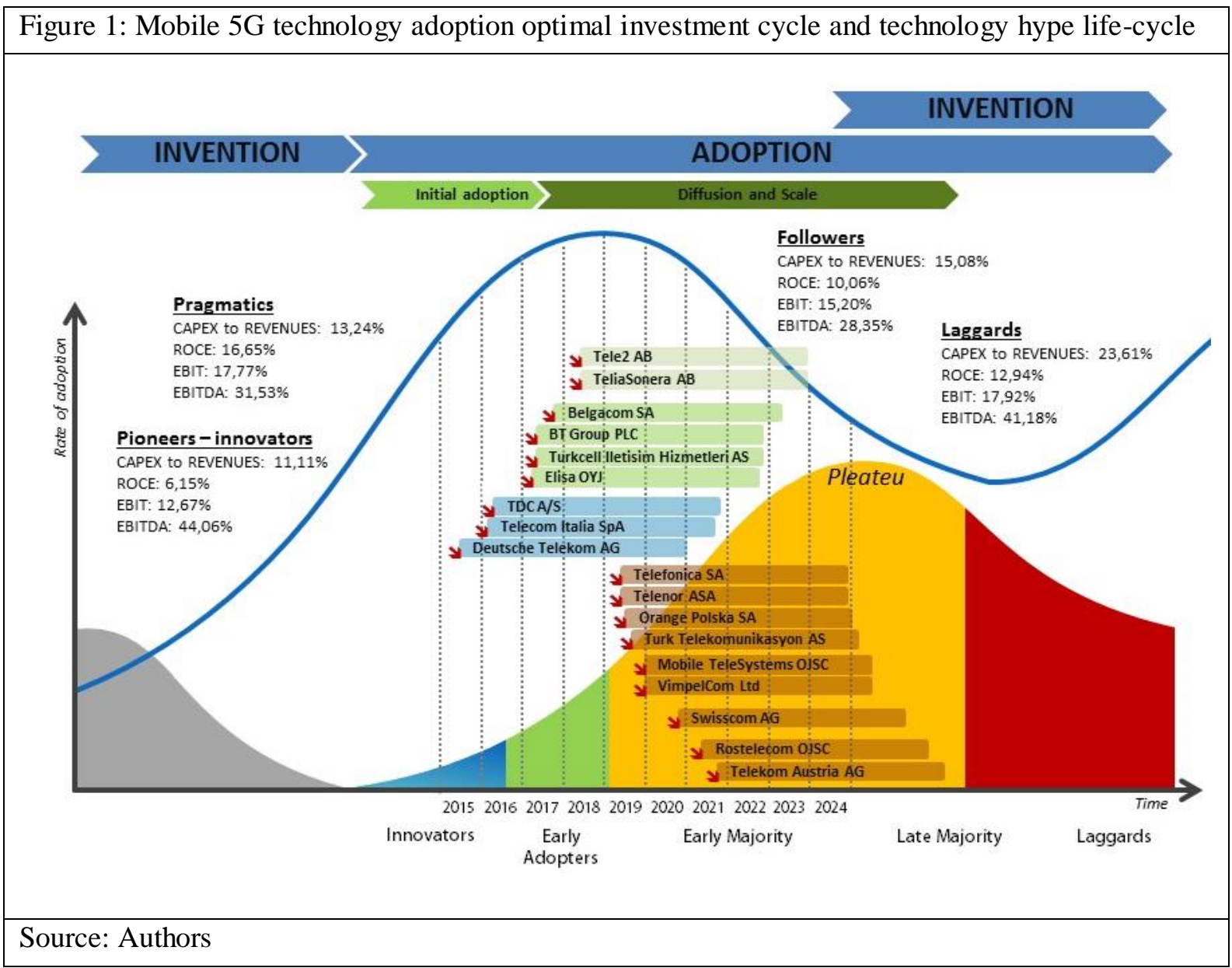

\section{Conclusion}

During recent decades, it had widely been agreed that technologies are one of the most important factors for economic growth. Due to this phenomenon, business enterprises need to identify the optimal timing of technological change in order to increase competitiveness, and create value of the company in an uncertain demanding environment. Analysis results confirmed that information 
regarding technological change is the same for all market players; selecting the time for technological investment depends on companies' strategic financial decisions and financial state; and finally, parameters that influence the willingness to invest appear to be CAPEX to revenues, ROCE, EBIT, and EBITDA, which combine in various ways according to investor roles.

\section{References}

Adamauskas, \& Krušinskas (2016). Optimal timing for technology shift in mature markets of mobile communication. Manuscript. New strategies for innovative performance. Strategic Change. John Wiley \& Sons.

Bar-Han, A., \& Maimon, O. (1993). An impulse-control method for investment decisions in dynamic technology. Managerial and Decision Economics, 14(1), 65-70. http://dx.doi.org/10.1002/mde.4090140108

Benaroch, M., \& Kauffman, R. J. (1999). A case for using real options pricing analysis to evaluate information technology project investments. Information Systems Research, 10(1), 70-86. http://dx.doi.org/10.1287/isre.10.1.70

Bhaskaran, S. R., \& Ramachandran, K. (2011). Managing Technology Selection and Development Risk in Competitive Environments. Production and Operations Management, 20: 541-555. http://dx.doi.org/10.1111/j.1937-5956.2010.01165.x

Biagini, B., Kuhl, L., Gallagher, K. S., \& Ortiz, C. (2014). Technology transfer for adoption. Nature Climate Change, 4(9), 828-834. http://dx.doi.org/10.1038/nclimate2305

Bohn, R. E. (1994). Measuring and managing technological knowledge. Sloan Management Review 36, 61-73. (Fall).

Bolton, P., Chen, H., \& Wang, N. (2013). Market timing, investment, and risk management. Journal of Financial Economics Volume 109, Issue 1, July 2013, Pages 40-62. http://dx.doi.org/10.1016/j.jfineco.2013.02.006

Bouis, R., Huisman, K., \& Kort, P. (2006). Investment in oligopoly under uncertainty: The accordion effect, Journal of Industrial Organization, Vol. 27, no. 2. pp. 320-331. http://dx.doi.org/10.1016/j.ijindorg.2008.10.003

Butler, A. W., Cornaggia, J., Grullon, G., \& Weston, J. P. (2011). Corporate financing decisions, managerial market timing, and real investment. Journal of Financial Economics, Volume 101, Issue 3, September 2011, Pages 666-683. http://dx.doi.org/10.1016/j.jfineco.2011.05.001

Chen H. \& Ma T. (2014). Technology adoption with limited foresight and uncertain technological learning. European Journal of Operational Research 239, 266-275. http://dx.doi.org/10.1016/j.ejor.2014.03.031

Chou, Y. C., Sung, W. C., Lin, G., \& Jahn, J. (2014). A comparative study on the performance of timing and sizing models of capacity expansion under volatile demand growth and finite equipment lifetime. Computers \& Industrial Engineering, 76, 98-108. http://dx.doi.org/10.1016/j.cie.2014.07.027

Crabtree, P. (2006), A framework for understanding technology and technological change. The Innovation Journal: The Public Sector Innovation Journal, Volume 11(1).

David, P., Hitt, M. A., \& Gimeno, J. (2001). The influence of activism by institutional investors on R\&D. Academy of Management Journal 44(1): 144-157. http://dx.doi.org/10.2307/3069342

Drejer, A. (2000). Integrating product and technology development. European Journal of Innovation Management 3 (3), 125 136. http://dx.doi.org/10.1108/14601060010334885

Feil, J. H., \& Musshoff, O. (2013). Modelling investment and disinvestment decisions under competition, uncertainty and different market interventions. Economic Modelling, 35, 443-452. http://dx.doi.org/10.1016/j.econmod.2013.07.026

Friar, J., \& Horwitch, M. (1985). The emergence of technology strategy: A new dimension of strategic management. Special Issue Technology in the Modern Corporation a Strategic Perspective. Volume 7, Issues 2-3, Pages 143-178. http://dx.doi.org/10.1016/0160-791X(85)90023-5

Gorodnichenko, Y., \& Schnitzer, M. (2013). Financial constraints and innovation: why poor countries don't catch up. Journal of the European Economic Association. 11(5):1115-1152. http://dx.doi.org/10.1111/jeea.12033

Grossmann, V. \& Steger, T. M. (2007) Growth, Development, and Technological Change. IZA Discussion Paper No. 2558.

Hagspiel, V., Huisman, K. J. M., \& Nunes, C. (2015). Optimal technology adoption when the arrival rate of new technologies changes. European Journal of Operational Research Volume 243, Issue 3, Pages 897-911.

http://dx.doi.org/10.1016/j.ejor.2014.12.024

Heffner, M., \& Sharif, N. (2008). Knowledge fusion for technological innovation in organizations. Journal of Knowledge Management 12 (2), 79-93. http://dx.doi.org/10.1108/13673270810859532

Henderson, V. (2010). Is corporate control effective when managers face investment timing decisions in incomplete markets? Journal of Economic Dynamics and Control, Volume 34, Issue 6, Pages 1062-1076.

http://dx.doi.org/10.1016/j.jedc.2010.02.009

Hori, K. \& Osano, H. (2013). Investment timing decisions of managers under endogenous contracts. Journal of Corporate Finance Volume 29, Pages 607-627. http://dx.doi.org/10.1016/j.jcorpfin.2013.11.013

Hsueh, C. F. (2011). An inventory control model with consideration of remanufacturing and product life cycle. International Journal of Production Economics 133, 645-652. http://dx.doi.org/10.1016/j.ijpe.2011.05.007

Huang, C., \& Da, Q. L. (2007). Optimal Timing and Probability Study of Generation Firm Investment under Power Price Uncertainty. Systems Engineering-Theory \& Practice, 27(6), 105-110. http://dx.doi.org/10.1016/S1874-8651(08)60040-X Ireland, R. D., \& Webb, J. W. (2007). Strategic entrepreneurship: Creating competitive advantage through streams of innovation. Business Horizons. Volume 50, Issue 1, Pages 49-59. http://dx.doi.org/10.1016/j.bushor.2006.06.002 
Jaffe, A. B., Newell, R. G., \& Stavins, R. N. (2002). Environmental Policy and Technological Change. Environmental and Resource Economics, Volume 22, Issue 1, pp 41-70. http://dx.doi.org/10.1023/A:1015519401088

Jakšić, M. L., \& Jakšić, M. (2012). Entrepreneurship in the knowledge based economy - The case of Serbia. Megatrend Review. Vol. 9 Issue 1, p35.

Jeon, H., \& Nishihara, M. (2014). Macroeconomic conditions and a firm's investment decisions. Finance Research Letters, 11(4), 398-409. http://dx.doi.org/10.1016/j.frl.2014.08.002

Jones, C. I. (2005). Growth and ideas, in: P. Aghion and S. Durlauf (eds.), Handbook of Economic Growth, North-Holland, Amsterdam. http://dx.doi.org/10.1016/s1574-0684(05)01016-6

Kamarianakis, Y., \& Xepapadeas, A. (2006). An irreversible investment model with a stochastic production capacity and fixed plus proportional adjustment costs. Journal of Economic No. 0708.

Kaplan, S., \& Tripsas, M., (2008). Thinking about technology: applying a cognitive lens to technical change. Research Policy 37, 790-805. http://dx.doi.org/10.1016/j.respol.2008.02.002

Kim, J. H., Lee, M. K., \& Sohn, S. Y. (2014). Investment timing under hybrid stochastic and local volatility. Chaos, Solitons \& Fractals 67 58-72. http://dx.doi.org/10.1016/j.chaos.2014.06.007

Kor, Y. Y. (2006), Direct and interaction effects of top management team and board compositions on R\&D investment strategy. Strat. Mgmt. J., 27: 1081-1099. http://dx.doi.org/10.1002/smj.554

Krishnan, V., \& Loch, C. H. (2005). A retrospective look at production and operations management articles on new product development. Prod. Oper. Manag. 14(4): 433-441. http://dx.doi.org/10.1111/j.1937-5956.2005.tb00231.x

Krušinskas, R., \& Vasiliauskaite, A. (2005). Technology Investment Decisions to Increase Company Value. Inzinerine Ekonomika-Engineering Economics, 4(44).

Lobel, I., Patel J., Vulcano G. \& Zhang J. (2015) Optimizing Product Launches in the Presence of Strategic Consumers. Social Science Research Network. http://dx.doi.org/10.2139/ssrn.2222266

Martinez, M. (2013). Perspectives on Innovation in Higher Education. The Jandris Center for Innovative Higher Education at the University of Minnesota.

Mokyr, J. (2005). Long-term economic growth and the history of technology, in: Aghion, P. and S.N. Durlauf (eds.), Handbook of Economic Growth, North-Holland, Amsterdam. http://dx.doi.org/10.1016/s1574-0684(05)01017-8

Moon, Y. (2010). Efforts and efficiency in partial outsourcing and investment timing strategy under market uncertainty. Computers \& Industrial Engineering, Volume 59, Issue 1, Pages 24-33. http://dx.doi.org/10.1016/j.cie.2010.02.010

Mukherji, N., Rajagopalan, B., \& Tanniru, M. (2006). A decision support model for optimal timing of investments in information technology upgrades. Decision Support Systems, 42(3), 1684-1696. http://dx.doi.org/10.1016/j.dss.2006.02.013

Ngwenyama, O., Guergachi, A., \& McLaren, T. (2007). Using the learning curve to maximize IT productivity: A decision analysis model for timing software upgrades. International Journal of Production Economics, 105(2), 524-535. http://dx.doi.org/10.1016/j.ijpe.2006.02.013

Nishihata, M., \& Shibata, T. (2013). The effects of external financing costs on investment timing and sizing decisions. Journal of Banking \& Finance 37, 1160-1175. http://dx.doi.org/10.1016/j.jbankfin.2012.11.014

Perez, C. (2001). Technological change and opportunities for development as a moving target. Cepal Review, No. 75, December, pp. 109-130.

Perez, C. (2002). Technological Revolutions and Financial Capital: The Dynamics of Bubbles and Golden Ages, Cheltenham, Elgar. http://dx.doi.org/10.4337/9781781005323

Perez, C. (2009). Technological revolutions and techno-economic paradigms. Cambridge journal of economics. http://dx.doi.org/10.1093/cje/bep051

Pertile, P. (2007). Investment in health technologies in a competitive model with real options. Journal of Public Economic Theory, 10 (5), 2008, pp. 923-952. Wiley Periodicals, Inc.

Pol, J. (2012). Decision Factors Influencing ITS Adoption. Final Report- Publication Number: FHWA-JPO-12-043 Research and Innovative Technology Administration. U.S. Department of Transportation.

Rogers, E. M. (2003). Diffusion of Innovations, 5th Edition. Simon and Schuster. ISBN 978-0-7432-5823-4.

Rogers, E. M. (2010). Diffusion of innovations. Simon and Schuster.

Rothaermel, F. T. (2008) Competitive advantage in technology intensive industries. Economic Growth, Volume 18, $201-225$. http://dx.doi.org/10.1016/S1048-4736(07)00007-0

Scarso, E. (1996). Timing the adoption of a new technology: an option-based approach, Management Decision 34/3, pages 41-48. MCB University Press [ISSN 0025-1747]. http://dx.doi.org/10.1108/00251749610113668

Schon, D. (1967). Technology and Change. Pergamon, London.

Shahmarichatghieh, M., Tolonen, A., \& Haapasalo, H. (2015) Product life cycle, technology life cycle and market life cycle; similarities, differences and applications. Technology, Innovation and Industrial Management Joint International Conference.

Shibata, T., \& Nishihara M. (2011). Interactions between investment timing and management effort under asymmetric information: Costs and benefits of privatized firms. European Journal of Operational Research 215, 688-696. http://dx.doi.org/10.1016/j.ejor.2011.06.025 
Stock, G. N., \& Tatikonda, M. V., (2000). A typology of project-level technology transfer processes. Journal of Operations Management 18, 719-737. http://dx.doi.org/10.1016/S0272-6963(00)00045-0

Svensson, E., Strömberg, A. B., \& Patriksson, M. (2011). A model for optimization of process integration investments under uncertainty. Energy, Volume 36, Issue 5, Pages 2733-2746. http://dx.doi.org/10.1016/j.energy.2011.02.013

Tan, K. S., Chong, S. C., Lin, B., \& Eze, U. C. (2009). Internet-based ICT adoption: Evidence from Malaysian SMEs. Industrial Management and Data Systems 109(2): 224-244. http://dx.doi.org/10.1108/02635570910930118

Taylor, M., \& Taylor, A. (2012). The technology life cycle: Conceptualization and managerial implications. International Journal of Production Economics. http://dx.doi.org/10.1016/j.ijpe.2012.07.006

Teixeira, A. C. (2012) Technological Change. InTech, ISBN 978-953-51-0509-1, http://dx.doi.org/10.5772/2314

Verganti, R. (2011). Radical Design and Technology Epiphanies: A New Focus for Research on Design Management. J Prod Innov Manag, 2011;28:384-388. http://dx.doi.org/10.1111/j.1540-5885.2011.00807.x

Whalley, A. E. (2011). Optimal R\&D investment for a risk-averse entrepreneur. Journal of Economic Dynamics \& Control 35, 413-429. http://dx.doi.org/10.1016/j.jedc.2009.11.009

Wickart, M., \& Madlener, R. (2007) Optimal technology choice and investment timing: A stochastic model of industrial cogeneration vs. heat-only production. Energy Economics, Volume 29, Issue 4, Pages 934-952. http://dx.doi.org/10.1016/j.eneco.2006.12.003

Wong, K. P. \& Yi, L. (2013). Irreversibility, mean reversion, and investment timing. Economic Modelling 30, $770-775$. http://dx.doi.org/10.1016/j.econmod.2012.10.007

Wong, K. P. (2010). The effects of irreversibility on the timing and intensity of lumpy investment. Economic Modelling, 27(1), 97-102. http://dx.doi.org/10.1016/j.econmod.2009.07.028

Wong, K. P. (2011), Progressive taxation and the intensity and timing of investment. Economic Modelling, Volume 28, Issues 1-2, Pages 100-108. http://dx.doi.org/10.1016/j.econmod.2010.09.020

Yagi, K., \& Takashima, R. (2012). The impact of convertible debt financing on investment timing. Economic Modelling, Volume 29, Issue 6, Pages 2407-2416. http://dx.doi.org/10.1016/j.econmod.2012.06.032 